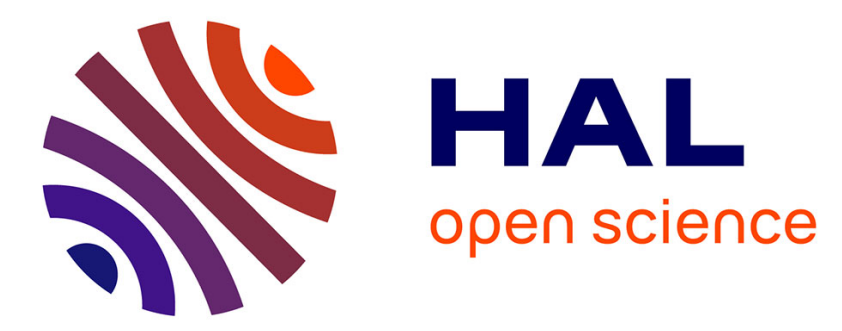

\title{
Asymmetric and nonlinear pass-through of crude oil prices to gasoline and natural gas prices
}

Ahmed Atil, Amine Lahiani, Duc Khuong Nguyen

\section{To cite this version:}

Ahmed Atil, Amine Lahiani, Duc Khuong Nguyen. Asymmetric and nonlinear pass-through of crude oil prices to gasoline and natural gas prices. Energy Policy, 2014, 65, pp.567-573. 10.1016/j.enpol.2013.09.064 . halshs-01022598

\section{HAL Id: halshs-01022598 \\ https://shs.hal.science/halshs-01022598}

Submitted on 7 Aug 2014

HAL is a multi-disciplinary open access archive for the deposit and dissemination of scientific research documents, whether they are published or not. The documents may come from teaching and research institutions in France or abroad, or from public or private research centers.
L'archive ouverte pluridisciplinaire HAL, est destinée au dépôt et à la diffusion de documents scientifiques de niveau recherche, publiés ou non, émanant des établissements d'enseignement et de recherche français ou étrangers, des laboratoires publics ou privés. 


\title{
Asymmetric and nonlinear pass-through of crude oil prices to gasoline and natural gas prices
}

\author{
Ahmed Atil \\ ESC Rennes Business School, France \\ ahmed.atil@esc-rennes.fr \\ Amine Lahiani \\ LEO-University of Orléans, France \\ amine.lahiani@univ-orleans.fr \\ Duc Khuong Nguyen* \\ IPAG Business School, 184, Boulevard Saint-Germain, 75006 Paris, France \\ Phone: +33 (0)1 53633600 | Fax: +33 (0)1 45444046 \\ duc.nguyen@ipag.fr \\ * Corresponding author
}

\begin{abstract}
In this article, we use the recently developed nonlinear autoregressive distributed lags (NARDL) model to examine the pass-through of crude oil prices into gasoline and natural gas prices. Our approach allows us to simultaneously test the short- and long-run nonlinearities through positive and negative partial sum decompositions of the predetermined explanatory variables. It also offers the possibility to quantify the respective responses of gasoline and natural gas prices to positive and negative oil price shocks from the asymmetric dynamic multipliers. The obtained results indicate that oil prices affect gasoline prices and natural gas prices in an asymmetric and nonlinear manner, but the price transmission mechanism is not the same. Important policy implications can be learned from the empirical findings.
\end{abstract}

Keywords: oil price shocks, gasoline, natural gas, NARDL model, asymmetric pass-through. JEL classification: C58; Q40; Q47 


\section{Introduction}

Understanding the pass-through of oil prices to gasoline and natural gas prices is of paramount importance not only for energy policy decision-making but also for portfolio risk management and optimal hedging issues. Indeed, prices of these energy sources influence the level of capital expenditure of almost all economic agents and the incentives to promote alternative energy sources. Investors in energy markets may find the tendency of the prices to adjust to a certain relative price relationship or parity as the basis for a trading strategy. For example, Brown and Yucel (2008) document that there was a 10-1 relationship between the price of one barrel of oil and the price of one million BTUs of natural gas in the 1990s but this relative price relationship declined to a 6-1 ratio more recently as the oil and natural gas prices rise.

The empirical literature on the oil price pass-through is extensive and has started with studies examining the relationship between oil prices and the macroeconomy. The study of Hamilton (1983) shows that rising oil prices are responsible for nine out of ten of the U.S. recessions since the Second World War, thus suggesting a negative impact of oil price changes on U.S. output growth. Most subsequent studies reach similar conclusions and attempt to explain the oil-economic growth nexus by the oil price pass-through to production cost, inflation expectation, monetary policy, and investor confidence (e.g., Mork, 1989; Hooker, 1996; Cologni and Manera, 2008). There is also evidence to suggest the existence of asymmetric and nonlinear links between oil price and economic growth, even though they become weaker in recent years (e.g., Hamilton, 2003; Kilian, 2008; Lardic and Mignon, 2008). Another major stream of research has focused on how oil prices are passed on to stock prices (e.g., Jones and Kaul, 1996; Sadorsky, 1999, Ciner, 2001; Arouri and Nguyen, 2010; Aloui et al., 2012). These studies document both linear and nonlinear significant effects of oil prices on equity prices, but the sign and strength of the effects depend on the state of the market, the nature of the economic sectors, and the oil-dependence profile of the considered country. 
A number of studies have recently investigated the pass-through of crude oil prices to the prices of refined petroleum products and other commodities. Most of them make use of a cointegration approach and focus on the oil-gasoline price relationships. It has been documented that downstream prices tend to respond to increases in upstream prices more rapidly than their responses to decreases in upstream prices. This asymmetric price interaction, initially discovered by Bacon (1991) as the "rockets and feathers" effects, then more or less confirmed by various studies (e.g., Borenstein et al., 1997; Bachmeier and Griffin, 2003; Chen et al., 2005; Grasso and Manera, 2007; Blair and Rezek, 2008; Meyler, 2009; Honarvar, 2009). For example, Borenstein et al. (1997) report evidence that gasoline prices adjust faster when oil prices increase than when they decrease.

Several studies have investigated the price transmission mechanisms between oil and natural gas, but most of them focus on the investigation of the linear relations between these prices (e.g., Yucel and Guo, 1994; Asche et al., 2006; Villar and Joutz, 2006; Brown and Yucel, 2008; Hartley et al., 2008). In general, past findings indicate evidence of a stable long-run relationship between the two prices as well as a directional influence from oil prices to natural gas prices. For example, Villar and Joutz (2006) show, from their bivariate VEC models, that a permanent shock of $20 \%$ in the WTI price leads to a $16 \%$ increase in the Henry Hub price. Brown and Yucel (2007) show, from an error-correction model that the movements in crude oil prices have a prominent role in shaping natural gas prices when the weather conditions, inventories and other additional factors are taken into account. Two recent studies, Grégoire et al. (2008), and Aloui et al. (2013), attempt to model the nonlinear links between crude oil and natural gas prices. While the former finds evidence of extreme comovement of these prices using Student- $t$ copulas, the latter relies on an extreme value theory - copula approach and documents the presence of extreme dependence only during the bullish market phases. The 
joint upward movements are typically explained by the simultaneous effects of increasing industrial and economic activities.

This article examines how oil prices are asymmetrically passed on to gasoline and natural gas prices over both the short and long run. We extend the extant literature by making use of a nonlinear autoregressive distributed lags (NARDL) model which consists in a dynamic errorcorrection representation allowing for the asymmetric responses of gasoline and natural gas prices to crude oil price changes. Shin et al. (2011) show that reliable long-run inferences can be achieved by bounds tests regardless of the integration orders of the variables in the system and that imposing either long-run symmetry or short-run symmetry or both simplifies the model to the traditional error-correction approach.

The investigation of nonlinear and asymmetric price transmissions between these energy commodities is motivated by both theoretical and empirical insights. Indeed, most economic and financial variables exhibit a nonlinear behavior over time, and that they may interact with each other in a nonlinear manner. This nonlinear behavior of time series can be driven by, among others, successive episodes of economic and financial crises (e.g., the 1997-1998 Asian financial crisis, the 2001 dot-com bubble burst, the 2007 subprime crisis in the United States, and the 2008-2009 global financial crisis), wars and extreme events (e.g., the 11 September 2001 terrorist attack, the Second Gulf war from March 2003 to May 2003, and the recent Arab Spring since 2010), geopolitical tensions, and sudden changes in business cycle as well as the complexity of financial markets induced by the heterogeneity of economic agents, the globalization, and the multiplicity of regulations. All these factors may cause unexpected changes in the behavior of economic and financial time series, which particularly induce structural breaks, asymmetric responses to news, and leverage effects. Under these conditions, the prices of crude oil, gasoline, and natural gas are likely to behave nonlinearly, and their joint dynamics seem to be more complex than a simple and stable relationships. 
Aloui et al. (2013) note several periods in which natural gas prices deviate from their historical relationships with oil prices owing to particular market conditions or the discovery of hydraulic fracturing. Serletis and Ricardo (2004) examine the strength of shared trends and cycles between crude oil prices and Henry Hub natural gas prices, and provide evidence to reject the hypothesis of common and codependent cycles. As to the potential of nonlinear links between crude oil and gasoline prices, it is also affected by the structure of retail markets, which depends on extraction, refinery and distribution. On the other hand, the asymmetric responses of gasoline prices to crude oil prices, which have become popular with the validation of the "rockets and feathers" hypothesis by the majority of studies in the energy economics literature, are often explained by factors such as oligopolistic behavior, inventory levels, production lags, and market competition structure (e.g., Bacon, 1991; Borenstein et al., 1997; Al Gudhea et al., 2007; Grasso and Manera, 2007). The asymmetric transmission between crude oil and natural gas prices can arise from the fact that the latter are not only substitutes, but also rivals in consumption and production of other energy sources (Aloui et al., 2013). Moreover, the crude oil market responds more to global economic, financial and geopolitical factors given its global nature, whereas natural gas prices are more sensitive to regional factors and affected by its own supply and demand disruptive shocks (e.g., extreme weather events, seasonality, and supply storage constraints).

Our empirical analysis, based on the spot prices of WTI crude oil, gasoline, and Henry Hub natural gas, provides evidence of short-run asymmetry in the oil-gasoline price relationships and long-run asymmetry in the oil-natural gas price relationships. Moreover, our results from the best-suited models for each pair of commodity prices indicate that the impact of oil price decreases on gasoline and natural gas prices is significantly larger than that of oil price increases. Our empirical evidence of asymmetric price transmission between crude oil and gasoline prices is obviously similar to that of, among others, Borenstein et al. (1997) and Chen et 
al. (2005). However, we are able to show that the asymmetry is short-run and that it takes about 8 months for the two prices to establish a new equilibrium state, given the dynamic adjustments of gasoline prices to negative and positive changes in oil prices.

The rest of the article is organized as follows. Section 2 introduces the empirical framework and describes the data. Section 3 reports the obtained results. Section 4 concludes the article.

\section{Methodology and data}

\subsection{The NARDL model}

It is now common that dynamic relationships between $I(1)$ variables can be reproduced via an error-correction model - ECM (Granger, 1981; Engle and Granger, 1987; Johansen, 1988). In its traditional form, the linear ECM specification without asymmetry in short- and long-run dynamics takes the following form

$$
\Delta y_{t}=\mu+\rho_{y} y_{t-1}+\rho_{w t i} w t i_{t-1}+\sum_{i=1}^{p-1} \alpha_{i} \Delta y_{t-i}+\sum_{i=0}^{q-1} \beta_{i} \Delta w t i_{t-1}+\varepsilon_{t}
$$

In our study, $w t i_{t}$ refers to the WTI oil prices, while $y_{t}$ represents either the gasoline prices or the natural gas prices. The symbol $\Delta$ denotes the price variations. Even though the model in Eq. (1) enables the investigation of the short- and long-run relationships between price variables, it becomes impertinent when these relationships are nonlinear and/or asymmetric, which is the case for crude oil, gasoline and natural gas as we pointed out in the introduction. That is why a nonlinear and asymmetric ECM is of great interest. We thus adopt the cointegrating NARDL model of Shin et al. (2011) that allows for short- and long-run asymmetries. This model uses the decomposition of the exogenous variable $w t i_{t}$ into its positive $\Delta w t i_{t}^{+}$and negative $\Delta w t i_{t}^{-}$partial sums of increases and decreases such as

$$
w t i_{t}^{+}=\sum_{j=1}^{t} \Delta w t i_{j}^{+}=\sum_{j=1}^{t} \max \left(\Delta w t i_{j}, 0\right) \text { and } w t i_{t}^{-}=\sum_{j=1}^{t} \Delta w t i_{j}^{-}=\sum_{j=1}^{t} \min \left(\Delta w t i_{j}, 0\right) .
$$


When the asymmetries in the short- and long-run dynamics are introduced into the standard ECM, Shin et al. (2011) show that Eq. (1) is extended to obtain a more general cointegration model as follows

$$
\Delta y_{t}=\mu+\rho_{y} y_{t-1}+\rho_{w t i}^{+} w t i_{t-1}^{+}+\rho_{w t i}^{-} w t i_{t-1}^{-}+\sum_{i=1}^{p-1} \alpha_{i} \Delta y_{t-i}+\sum_{i=0}^{q-1}\left(\beta_{i}^{+} \Delta w t i_{t-i}^{+}+\beta_{i}^{-} \Delta w t i_{t-i}^{-}\right)+\varepsilon_{t}
$$

The superscripts (+) and (-) in Eq. (2) denote the positive and negative partial sums decomposition defined above. $p$ and $q$ represent the lag order for the dependent variable and the exogenous variable in distributed lag part, respectively. The long-run symmetry can be tested by using a Wald test of the null hypothesis $\theta^{+}=\theta^{-}$with $\theta^{+}=-\rho_{w t i}^{+} / \rho_{y}$ and $\theta^{-}=-\rho_{w t i}^{-} / \rho_{y}$ being the positive and negative long-run coefficients. The short-run adjustment to a positive and a negative shock in the price of oil is captured by the parameters $\beta_{i}^{+}$and $\beta_{i}^{-}$, respectively. The short-run symmetry can equally be tested by using a standard Wald test of the null hypothesis $\beta_{i}^{+}=\beta_{i}^{-}$for all $i=0, \ldots, q-1$. The model in Eq. (2) reduces to the traditional ECM if both null hypotheses of short-run and long-run symmetry are not rejected. The non-rejection of either the long-run symmetry or the short-run symmetry will yield the cointegrating NARDL model with short-run asymmetry in Eq. (3) and with long-run asymmetry in Eq. (4), respectively.

$$
\begin{aligned}
& \Delta y_{t}=\mu+\rho_{y} y_{t-1}+\rho_{w t i} w t i_{t-1}+\sum_{i=1}^{p-1} \alpha_{i} \Delta y_{t-i}+\sum_{i=0}^{q-1}\left(\beta_{i}^{+} \Delta w t i_{t-i}^{+}+\beta_{i}^{-} \Delta w t i_{t-i}^{-}\right)+\varepsilon_{t} \\
& \Delta y_{t}=\mu+\rho_{y} y_{t-1}+\rho_{w t i}^{+} w t i_{t-1}^{+}+\rho_{w t i}^{-} w t i_{t-1}^{-}+\sum_{i=1}^{p-1} \alpha_{i} \Delta y_{t-i}+\sum_{i=0}^{q-1} \beta_{i} \Delta w t i_{t-i}+\varepsilon_{t}
\end{aligned}
$$

When asymmetry is detected in the ARDL model (either in the short run, in the long run or in both), the asymmetric responses to positive and negative shocks (i.e., positive or negative variations of the WTI oil prices) are respectively captured by the positive and negative dynamic multipliers associated with unit changes in $w t i^{+}$and $w t i^{-}$as follows 
$m_{h}^{+}=\sum_{j=0}^{h} \frac{\partial y_{t+j}}{\partial w t i_{t}^{+}}$and $m_{h}^{-}=\sum_{j=0}^{h} \frac{\partial y_{t+j}}{\partial w t i_{t}^{-}}$with $h=0,1,2, \ldots$

where $h \rightarrow \infty, m_{h}^{+} \rightarrow \theta^{+}$, and $m_{h}^{-} \rightarrow \theta^{-}$by construction. Based on the estimated multipliers, one can observe, following a shock affecting the system, dynamic adjustments from the initial equilibrium to the new equilibrium between the system variables.

\subsection{Data}

Our data consist of time series of monthly spot closing prices for WTI crude oil, gasoline, and Henry Hub natural gas. They are obtained from Bloomberg and cover the period from January 1997 to September 2012. Commodity prices are expressed in US dollars. Table 1 presents the descriptive statistics for price series as well as their stochastic properties. The monthly average prices range from $\$ 1.4360$ per gallon for gasoline to $\$ 51.536$ per barrel for crude oil. On a monthly basis, the WTI oil and gasoline prices reach their maximum value of $\$ 133.88$ and $\$ 1.436$ respectively in July 2008 , while the highest peak in natural gas price $(\$ 13.420)$ is observed in October 2005. All the series are positively skewed and display significant excess kurtosis, which means that they have fatter tails and longer left tails than a normal distribution. The Jarque-Bera test indicates the non-normality of all the price series.

Table 1. Stochastic properties of commodity price series

\begin{tabular}{lccc}
\hline & Crude oil & Gasoline price & Natural gas \\
\hline Mean & 51.536 & 1.436 & 4.794 \\
Maximum & 133.880 & 3.292 & 13.420 \\
Minimum & 11.350 & 0.307 & 1.720 \\
Standard deviation & 30.152 & 0.831 & 2.410 \\
Skewness & 0.580 & 0.572 & 1.090 \\
Kurtosis & 2.274 & 2.117 & 4.248 \\
JB & $14.767^{+}$ & $16.455^{+}$ & $49.706^{+}$ \\
ZA & -4.667 & -3.615 & -4.437 \\
\hline
\end{tabular}

Notes: JB is the empirical statistics of the Jarque-Bera test for normality. ZA is the empirical statistics of the Zivot and Andrews (1992) unit root test which is robust to structural breaks. ${ }^{+},{ }^{++}$, and ${ }^{+++}$indicate rejection of the null hypotheses of normality and unit root.

Table 1 also reports the results of the Zivot-Andrews unit root tests. The use of this test is justified by the potential of structural change in the price series over the study period which is characterized by several episodes of crises and important terrorist and geopolitical events. The 
obtained results indicate that the three price series are not stationary at the conventional levels, and are thus appropriate for the application of the NARDL model.

\section{Results}

We first estimate the specification models developed in Eqs. (1)-(4) for the oil price passthrough to gasoline prices and natural gas prices. The obtained results are reported in Tables 2-3 respectively. Wald tests are then conducted to examine the hypotheses of short-run and long-run symmetry. The results from these tests applied to the estimates of the NARDL model with short-run and long-run asymmetries indicate that the long-run symmetry cannot be rejected for the oil-gasoline price relationships, but does not occur in the case of oil-natural gas price relationships. The short-run symmetry is rejected by the Wald tests for oil-gasoline case at the 5\% level, but does occur for oil-natural gas case. Similar conclusions are drawn from the models incorporating either long-run or short-run symmetry. The symmetric shortrun relationship between oil prices and gasoline prices can be partially explained by the fact that gasoline is derived from crude oil and this feedstock accounts for more than $60 \%$ of the cost of gasoline. This asymmetry may also come from the public's discretionary spending adjustments in order to keep the gasoline prices stable. Nevertheless, the symmetric response is expected over the long-run because the supply of gasoline can be adjusted more easily. Differently, the symmetric short-run link between crude oil and natural gas prices can be explained by factors such as capacity conversion, natural gas-to-oil substitution, and different costs of transportation justify. ${ }^{1}$

Overall, these findings, consistent with the empirical evidence of the majority of past studies, clearly suggest that linear models are misspecified and thus do not provide the accurate fit to the underlying data. Frey and Manera (2007) review the existing empirical literature on price asymmetries in commodities from 38 studies in terms of econometric models, type of asym-

\footnotetext{
${ }^{1} \mathrm{We}$ are particularly grateful to an anonymous reviewer for these valuable suggestions.
} 
metries and empirical findings. They find that half of past studies report evidence of asymmetry, five of them document the symmetry and the remaining studies report mixed results. In what follows, we detail the price transmission mechanism for each case. Note finally that all the models we use are correctly specified as the residual series do not exhibit ARCH effects at the 5\% level, except for the NARDL model with short-run asymmetry for crude oil and natural gas. The non-normality of residual series is only found for the oil-natural gas case.

\subsection{Pass-through of oil prices to gasoline prices}

Table 2 shows that the estimated coefficients of all the four symmetric and asymmetric passthrough models are highly significant at the $1 \%$ and 5\% levels, thus indicating that the price of crude oil is an important driver of gasoline prices. According to the AIC and SIC information criteria and Wald symmetry tests, the $\operatorname{NARDL}(3,2)$ specification with short-run asymmetry is the most suitable model for the oil-gasoline case. ${ }^{2}$ The results of the best-suited model show that the long-run coefficient is positive (0.976) and significant at the $1 \%$ level, indicating that oil price increases (decreases) cause the price of gasoline to move up (down). Comparatively, the restricted symmetric model also yields a significant long-run coefficient of similar magnitude (0.979), but definitively masks the short-run asymmetric effects of oil prices on gasoline prices. We indeed find that contemporaneous increases and decreases in the price of crude oil have a positive effect on gasoline prices, while the one-period lagged changes in oil prices are negatively passed through to gasoline prices. This finding corroborates the results of previous studies because not only gasoline prices respond asymmetrically to oil price movements, but there is also a temporal delay in their reaction to changes in crude oil prices. Over the short-run, the relationship between the two prices can be positive or negative depending on other factors that affect the gasoline market. It is, for example, possible that the gasoline market is facing an increase or decrease in gasoline inventories. Borenstein and

\footnotetext{
${ }^{2}$ The best model is the one that has the lowest AIC and SIC values.
} 
Shephard (2002) argue that refineries can adjust the production of gasoline or the level of gasoline inventory to change the supply and the price of gasoline when crude oil prices change, but these alternative adjustments may be very costly over the short period of time, which leads to a temporal delay in the response of gasoline prices to crude oil prices.

Taking the asymmetric effects into account, we see that in the short-run, an increase of $1 \%$ in oil prices entails a cumulative increase of $0.483 \%$ in gasoline price and that a decrease of $1 \%$ in oil prices leads to a cumulative decrease of $1.095 \%$ in gasoline price. Overall, the empirical findings reveal the price of crude oil as an important driver of gasoline prices, reflecting the fact that crude oil is the primary raw material used to derive gasoline as well as other refined petroleum products such as heating oil and diesel fuel. They also suggest that oil price decreases are passed on to gasoline prices over the short run and more importantly than the oil price increases. Our results are thus inconsistent with those of Borenstein et al. (1997) who find no evidence of asymmetry in wholesale gasoline prices from an error-correction model with daily spot gasoline and crude-oil price data over the period 1985-1998. The results of Chen et al. (2005) are also not supported by ours as they indicate that the observed asymmetry in retail gasoline price transmission primarily occurs downstream of the transmission process but not upstream.

\subsection{Pass-through of oil prices to natural gas prices}

Although the price ratio between crude oil and natural gas has recently changed as compared to its previous level, they still tend to comove through time. Their substitutes in consumption and also complements as well as rivals in production of other energy sources including electricity and heating oil may however induce complicated price links than common expectations of linear causality effects. The results of the Wald tests for symmetries, reported in Table 3, show that the NARDL(2,3) specification with long-run asymmetry is selected as the bestsuited model for the oil-natural gas price case. In the specification allowing for both long-run 
and short-run asymmetries, most of the coefficients associated with the short-run asymmetric effects of oil prices are insignificant. The price of natural gas is only affected by the contemporaneous change and the one-month lagged decline in the price of oil. The results of the best-suited model indicate that natural gas prices react more to oil price decreases than to oil price increases in the long-run. It can clearly be seen that an increase of $1 \%$ in the price of crude oil causes natural gas prices to rise by $1.247 \%$, while a decrease of $1 \%$ in the price of crude oil is associated with a fall of $1.666 \%$ in natural gas prices. These findings are also confirmed by those of the model incorporating both short- and long-run asymmetries. 
Table 2. Estimation results for oil price pass-through to gasoline prices

\begin{tabular}{|c|c|c|c|c|c|c|c|}
\hline \multicolumn{2}{|c|}{ Symmetric ARDL } & \multicolumn{2}{|c|}{ NARDL with LR asymmetry } & \multicolumn{2}{|c|}{ NARDL with SR asymmetry } & \multicolumn{2}{|c|}{ NARDL with LR and SH asymmetry } \\
\hline gasoline $_{t-1}$ & $\begin{array}{c}-0.314^{* * * *} \\
(0.061)\end{array}$ & gasoline $_{t-1}$ & $\begin{array}{c}-0.322^{* * * *} \\
(0.062)\end{array}$ & gasoline $_{t-1}$ & $\begin{array}{c}-0.347^{* * * *} \\
(0.060)\end{array}$ & gasoline $_{t-1}$ & $\begin{array}{l}-0.359^{* * * *} \\
(0.061) .)\end{array}$ \\
\hline$w t i_{t-1}$ & $\begin{array}{l}0.308^{* * * *} \\
(0.059)\end{array}$ & $w t i_{t-1}^{+}$ & $\begin{array}{l}0.303^{* * * *} \\
(0.060)\end{array}$ & $w t i_{t-1}$ & $\begin{array}{l}0.338 \\
(0.058)\end{array}$ & $w t i_{t-1}^{+}$ & $\begin{array}{l}0.334^{* * * *} \\
(0.058)\end{array}$ \\
\hline$\Delta_{\text {gasoline }}{ }_{t-1}$ & $\begin{array}{l}0.183^{* * *} \\
(0.074)\end{array}$ & $w t i_{t-1}^{-}$ & $\begin{array}{l}0.297^{* * * *} \\
(0.060)\end{array}$ & $\Delta$ gasoline $_{t-1}$ & $\begin{array}{l}0.198 \\
(0.072)\end{array}$ & $w t i_{t-1}^{-}$ & $\begin{array}{l}0.327^{* * * *} \\
(0.059)\end{array}$ \\
\hline$\Delta$ gasoline $_{t-2}$ & $\begin{array}{c}-0.104^{* *} \\
(0.041)\end{array}$ & $\Delta$ gasoline $_{t-1}$ & $\begin{array}{l}0.184^{* * *} \\
(0.074)\end{array}$ & $\Delta$ gasoline $_{t-2}$ & $\begin{array}{c}-0.086 \\
(0.040)\end{array}$ & $\Delta_{\text {gasoline }}{ }_{t-1}$ & $\begin{array}{l}0.198^{* * * *} \\
(0.072)\end{array}$ \\
\hline$\Delta w t i_{t}$ & $\begin{array}{l}1.060^{* * *} \\
(0.049)\end{array}$ & $\Delta$ gasoline $_{t-2}$ & $\begin{array}{l}-0.097^{* *} \\
(0.041)\end{array}$ & $\Delta w t i_{t}^{+}$ & $\begin{array}{l}0.739^{\text {***** }} \\
(0.096)\end{array}$ & $\Delta$ gasoline $_{t-2}$ & $\begin{array}{l}-0.078^{*} \\
(0.041)\end{array}$ \\
\hline$\Delta w t i_{t-1}$ & $\begin{array}{l}-0.183^{* *} \\
(0.091)\end{array}$ & $\Delta w t i_{t}$ & $\begin{array}{l}1.049^{* * * *} \\
(0.050)\end{array}$ & $\Delta w t i_{t}^{-}$ & $\begin{array}{l}1.325^{* * *} \\
(0.086)\end{array}$ & $\Delta w t i_{t}^{+}$ & $\begin{array}{l}0.721^{* * * *} \\
(0.097)\end{array}$ \\
\hline Constant & $\begin{array}{c}-0.106^{* * * *} \\
(0.021)\end{array}$ & $\Delta w t i_{t-1}$ & $\begin{array}{l}-0.176^{*} \\
(0.091)\end{array}$ & $\Delta w t i_{t-1}^{+}$ & $\begin{array}{c}-0.256^{* *} \\
(0.115)\end{array}$ & $\Delta w t i_{t}^{-}$ & $\begin{array}{l}1.313^{* * * *} \\
(0.086)\end{array}$ \\
\hline & & Constant & $\begin{array}{c}-0.119^{* * * *} \\
(0.024)\end{array}$ & $\Delta w t i_{t-1}^{-}$ & $\begin{array}{l}-0.230^{*} \\
(0.123)\end{array}$ & $\Delta w t i_{t-1}^{+}$ & $\begin{array}{l}-0.262^{* *} \\
(0.115)\end{array}$ \\
\hline & & & & Constant & $\begin{array}{c}-0.095^{* * * *} \\
(0.020)\end{array}$ & $\Delta w t i_{t-1}^{-}$ & $\begin{array}{l}-0.207^{*} \\
(0.214)\end{array}$ \\
\hline & & & & & & Constant & $\begin{array}{c}-0.112^{* * * *} \\
(0.024)\end{array}$ \\
\hline$L_{w t i}$ & $\begin{array}{l}0.979^{* * *} \\
{[0.000]}\end{array}$ & $L_{w t i^{+}}$ & $\begin{array}{c}0.939^{* * * *} \\
{[0.000]}\end{array}$ & $L_{w t i}$ & $\begin{array}{l}0.976 * * * \\
{[0.000]}\end{array}$ & $L_{w t i^{+}}$ & $\begin{array}{l}0.932^{* * * *} \\
{[0.000]}\end{array}$ \\
\hline & & $L_{w t i^{-}}$ & $\begin{array}{l}0.921^{* * * *} \\
{[0.000]}\end{array}$ & & & $L_{w t i^{-}}$ & $\begin{array}{l}0.912^{* * * *} \\
{[0.000]}\end{array}$ \\
\hline AIC & -534.658 & AIC & -533.719 & AIC & -545.591 & AIC & -545.305 \\
\hline SIC & -512.078 & SIC & -507.912 & SIC & -516.559 & SIC & -513.047 \\
\hline JB & $3.009[0.222]$ & $\mathrm{JB}$ & $4.350[0.114]$ & $\mathrm{JB}$ & $2.263[0.322]$ & JB & $2.892[0.235]$ \\
\hline $\mathrm{ARCH}$ & $6.357[0.273]$ & $\mathrm{ARCH}$ & $6.717[0.243]$ & $\mathrm{ARCH}$ & $7.291[0.120]$ & $\mathrm{ARCH}$ & $7.714[0.173]$ \\
\hline & & $W_{L R}$ & $1.031[0.311]$ & $W_{S R}$ & $8.906[0.003]$ & $W_{L R}$ & $1.662[0.199]$ \\
\hline & & & & & & $W_{S R}$ & $9.820[0.002]$ \\
\hline
\end{tabular}

Notes: the SIC information criterion selects $p=3$ and $q=2$ as the optimal lag length. We employ a general-to-specific approach to select the final specifications by fixing max $p=$ max $q$ $=5$. $L_{w t i^{+}}$and $L_{w t i^{-}}$indicate the positive and negative long-run coefficients respectively. AIC and SIC are information criteria. JB and ARCH are the empirical statistics of the JarqueBera test for normality and the Engle (1982) test for conditional heteroscedasticity, respectively. $W_{L R}$ denotes the Wald test for long-run symmetry, while $W_{S R}$ refers to the Wald test for short-run symmetry examining the hypothesis $\sum_{i=0}^{p-1} \beta_{i}^{+}=\sum_{i=0}^{p-1} \beta_{i}^{-}$in Eq. (3). Standard errors of the estimated coefficients are in parenthesis. The $p$-values of statistical tests are in brackets. Bold numbers indicate the best model. 
Table 3. Estimation results for oil price pass-through to natural gas prices

\begin{tabular}{|c|c|c|c|c|c|c|c|}
\hline \multirow{2}{*}{$\operatorname{NatGas}_{t-1}$} & \multirow{2}{*}{$\begin{array}{c}\text { Symmetric ARDL } \\
-0.053^{* *} \\
(0.024)\end{array}$} & \multicolumn{2}{|c|}{ NARDL with LR asymmetry } & \multicolumn{2}{|c|}{ NARDL with SR asymmetry } & \multicolumn{2}{|c|}{ NARDL with LR and SH asymmetry } \\
\hline & & NatGas $_{t-1}$ & $\begin{array}{c}-0.086 \\
(0.028)\end{array}$ & $\operatorname{NatGas}_{t-1}$ & $\begin{array}{c}-0.054^{* * *} \\
(0.025)\end{array}$ & NatGas $_{t-1}$ & $\begin{array}{l}-0.091^{* * * *} \\
(0.028)\end{array}$ \\
\hline$w t i_{t-1}$ & $\begin{array}{c}0.011 \\
(0.019)\end{array}$ & $w t i_{t-1}^{+}$ & $\begin{array}{l}0.107 \\
(0.044)\end{array}$ & $w t i_{t-1}$ & $\begin{array}{c}0.011 \\
(0.019)\end{array}$ & $w t i_{t-1}^{+}$ & $\begin{array}{l}0.120^{* * * *} \\
(0.045)\end{array}$ \\
\hline$\Delta N a t G a s_{t-1}$ & $\begin{array}{c}0.051 \\
(0.074)\end{array}$ & $w t i_{t-1}^{-}$ & $\begin{array}{l}0.142^{* *} \\
(0.058)\end{array}$ & $\Delta$ NatGas $_{t-1}$ & $\begin{array}{c}0.046 \\
(0.074)\end{array}$ & $w t i_{t-1}^{-}$ & $\begin{array}{l}0.161^{* * *} \\
(0.060)\end{array}$ \\
\hline$\Delta w t i_{t}$ & $\begin{array}{l}0.318^{* * * *} \\
(0.115)\end{array}$ & $\Delta$ NatGas $_{t-1}$ & $\begin{array}{c}0.048 \\
(0.073)\end{array}$ & $\Delta w t i_{t}^{+}$ & $\begin{array}{l}0.501^{* * *} \\
(0.097)\end{array}$ & $\Delta$ NatGas $_{t-1}$ & $\begin{array}{c}0.037 \\
(0.073)\end{array}$ \\
\hline$\Delta w t i_{t-1}$ & $\begin{array}{l}-0.074 \\
(0.120)\end{array}$ & $\Delta w t i_{t}$ & $\begin{array}{l}0.394^{* * * *} \\
(0.118)\end{array}$ & $\Delta w t i_{t}^{-}$ & $\begin{array}{c}0.198 \\
(0.207)\end{array}$ & $\Delta w t i_{t}^{+}$ & $\begin{array}{l}0.602^{* *} \\
(0.231)\end{array}$ \\
\hline$\Delta w t i_{t-2}$ & $\begin{array}{l}0.215^{*} \\
(0.115)\end{array}$ & $\Delta w t i_{t-1}$ & $\begin{array}{l}-0.122 \\
-0.120)\end{array}$ & $\Delta w t i_{t-1}^{+}$ & $\begin{array}{c}0.297 \\
(0.234)\end{array}$ & $\Delta w t i_{t}^{-}$ & $\begin{array}{c}0.286 \\
(0.206)\end{array}$ \\
\hline \multirow[t]{5}{*}{ Constant } & $\begin{array}{l}0.070^{* * *} \\
(0.032)\end{array}$ & $\Delta w t i_{t-2}$ & $\begin{array}{l}0.145 \\
(0.117)\end{array}$ & $\Delta w t i_{t-1}^{-}$ & $\begin{array}{l}-0.361^{*} \\
(0.215)\end{array}$ & $\Delta w t i_{t-1}^{+}$ & $\begin{array}{c}0.309 \\
(0.230)\end{array}$ \\
\hline & & Constant & $\begin{array}{l}0.172^{* * * *} \\
(0.053)\end{array}$ & $\Delta w t i_{t-2}^{+}$ & $\begin{array}{c}0.136 \\
(0.231)\end{array}$ & $\Delta w t i_{t-1}^{-}$ & $\begin{array}{l}-0.455^{* * *} \\
(0.216)\end{array}$ \\
\hline & & & & $\Delta w t i_{t-2}^{-}$ & $\begin{array}{l}0.350^{*} \\
(0.204)\end{array}$ & $\Delta w t i_{t-2}^{+}$ & $\begin{array}{c}0.171 \\
(0.227)\end{array}$ \\
\hline & & & & Constant & $\begin{array}{l}0.045^{* * * *} \\
(0.037)\end{array}$ & $\Delta w t i_{t-2}^{-}$ & $\begin{array}{c}0.189 \\
(0.210)\end{array}$ \\
\hline & & & & & & Constant & $\begin{array}{l}0.150^{* * * *} \\
(0.054)\end{array}$ \\
\hline \multirow[t]{2}{*}{$L_{w t i}$} & $\begin{array}{c}0.208 \\
{[0.510]}\end{array}$ & $L_{w t i^{+}}$ & $\begin{array}{l}1.247^{* * * *} \\
{[0.002]}\end{array}$ & $L_{w t i}$ & $\begin{array}{c}0.211 \\
{[0.497]}\end{array}$ & $L_{w t i^{+}}$ & $\begin{array}{l}1.320^{* * *} \\
{[0.001]}\end{array}$ \\
\hline & & $L_{w t i^{-}}$ & $\begin{array}{l}1.666^{* * * *} \\
{[0.003]}\end{array}$ & & & $L_{w t i^{-}}$ & $\begin{array}{l}1.764^{* * * *} \\
{[0.001]}\end{array}$ \\
\hline AIC & -219.079 & AIC & -222.854 & AIC & -217.609 & AIC & -222.756 \\
\hline SIC & -196.499 & SIC & -197.048 & SIC & -185.352 & SIC & -187.268 \\
\hline JB & $27.554[0.000]$ & $\mathrm{JB}$ & $38.187[0.000]$ & $\mathrm{JB}$ & $1.788[0.409]$ & $\mathrm{JB}$ & $46.383[0.000]$ \\
\hline \multirow{3}{*}{$\mathrm{ARCH}$} & $2.386[0.793]$ & $\mathrm{ARCH}$ & $2.315[0.804]$ & $\mathrm{ARCH}$ & $12.148[0.033]$ & $\mathrm{ARCH}$ & $3.491[0.625]$ \\
\hline & & $W_{L R}$ & $6.580[0.011]$ & $W_{S R}$ & $1.723[0.191]$ & $W_{L R}$ & $8.122[0.005]$ \\
\hline & & & & & & $W_{S R}$ & $3.427[0.066]$ \\
\hline
\end{tabular}

Notes: the SIC information criterion selects $p=2$ and $q=3$ as the optimal lag length. We employ a general-to-specific approach to select the final specifications by fixing max $p=$ max $\mathrm{q}=5$. $L_{w t i^{+}}$ and $L_{w t i^{-}}$indicate the positive and negative long-run coefficients respectively. AIC and SIC are information criteria. $W_{L R}$ denotes the Wald test for long-run symmetry, while $W_{S R}$ refers to the Wald test for short-run symmetry examining the hypothesis $\sum_{i=0}^{p-1} \beta_{i}^{+}=\sum_{i=0}^{p-1} \beta_{i}^{-}$in Eq. (3). JB and ARCH are the empirical statistics of the Jarque-Bera test for normality and the Engle (1982) test for conditional heteroscedasticity, respectively. Standard errors are in parenthesis. The $p$-values of statistical tests are in brackets. Bold numbers indicate the best model. 


\subsection{Asymmetric adjustment paths}

The asymmetric adjustments from an initial long-run equilibrium to a new long-run equilibrium after a negative or positive unitary shock affecting the crude oil market can be learned from the dynamic multipliers. Figures 1-2 show the predicted dynamic multipliers for the adjustment of gasoline and natural gas prices under the four NARDL specifications we consider. The asymmetry curve depicts the linear combination of the dynamic multipliers associated with positive and negative shocks. The positive and negative change curves provide the information about the asymmetric adjustment to positive and negative shocks at a given forecasting horizon respectively. Lower band and upper band for asymmetry indicate the 95\% confidence interval.

\section{Figure 1}

Cumulative asymmetric adjustments of gasoline prices

Model with LR and SR asymmetry

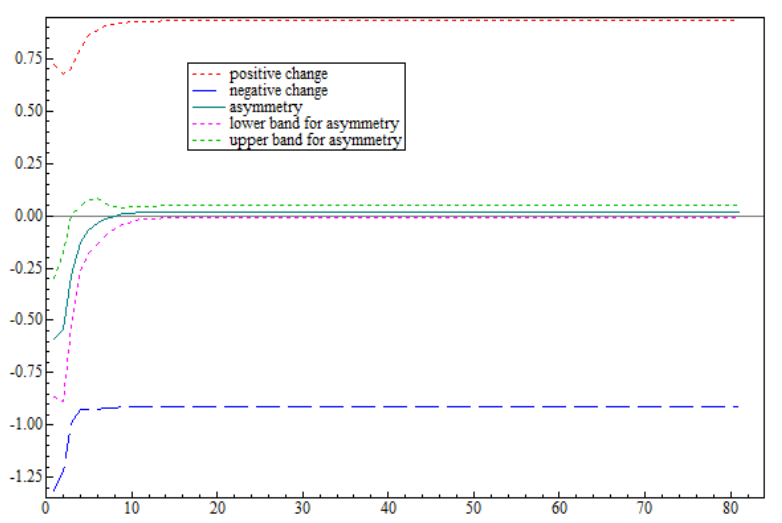

Model with LR asymmetry and SR symmetry

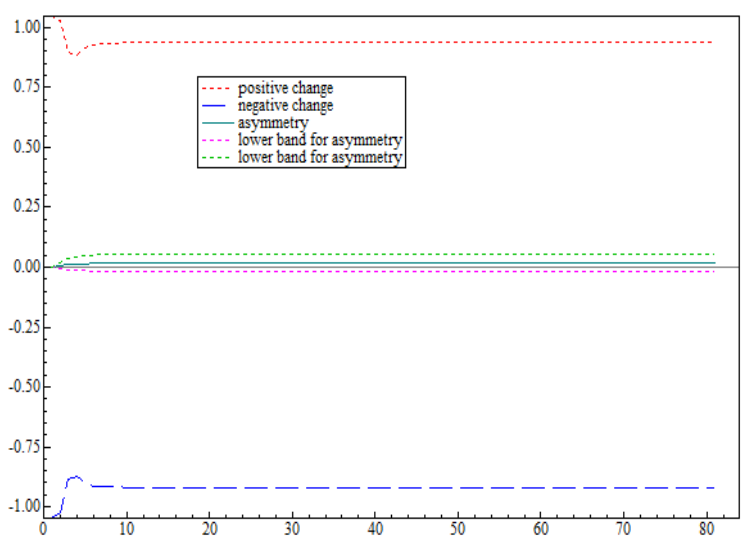

Model with LR symmetry and SR asymmetry

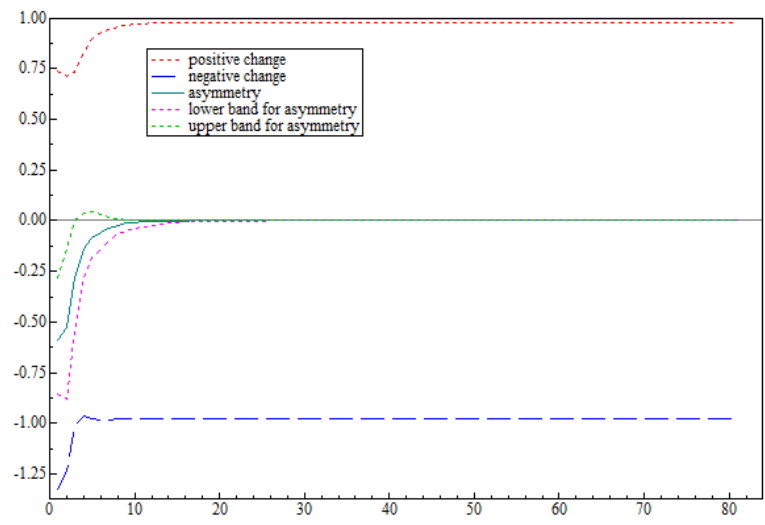

Symmetric model

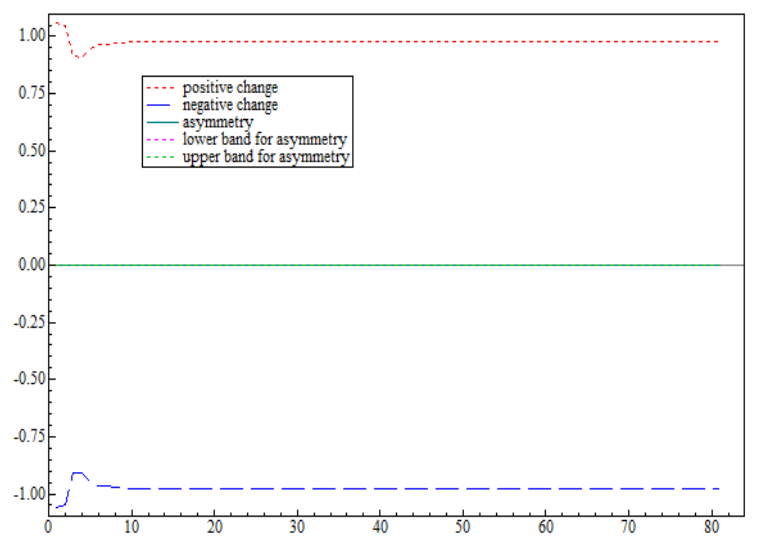


Figure 2

Cumulative asymmetric adjustments of natural gas prices

Model with LR and SR asymmetry

Model with LR symmetry and SR asymmetry
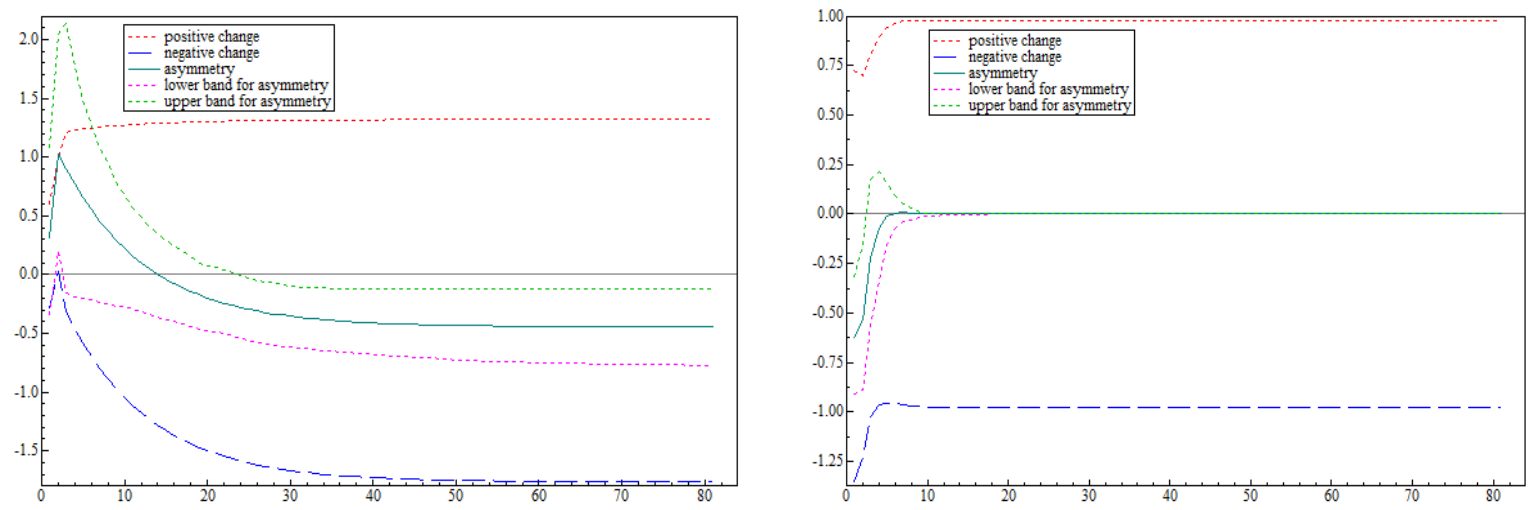

Model with LR asymmetry and SR symmetry

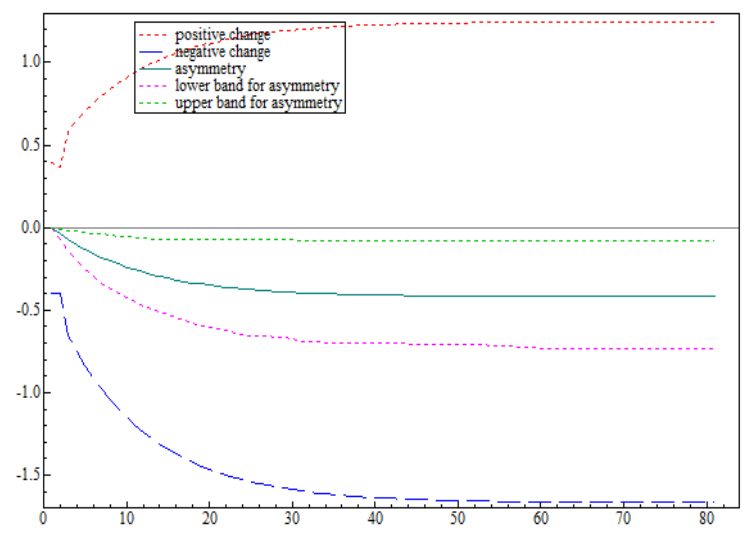

Symmetric model

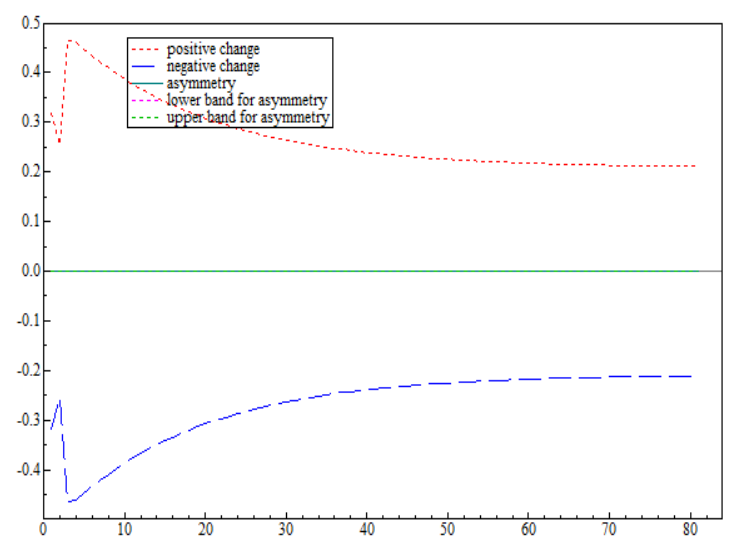

Overall, the shape of the dynamic multipliers changes when short-run asymmetry or long-run asymmetry or both are introduced in the model. Considering the best-suited model for oilgasoline case (i.e., model with long-run symmetry and short-run asymmetry), the short-run adjustment path shows a greater reaction of gasoline price to a unitary decline in the price of oil. The cumulative price responses are negative and significant. The new equilibrium state between the two prices is reached after 8 months. Regarding the oil-natural gas pair, the dynamic multiplier computed from the best-suited model (i.e., model with long-run asymmetry and short-run symmetry) provides strong evidence of negative adjustment of natural gas prices. The asymmetric oil pass-through is however very persistent over time and practically takes a lot of time to converge to the long-run multipliers. 


\section{Concluding remarks}

Appropriate energy policies usually require the strategic development of alternative energy sources and/or the adjustments of gasoline and natural gas prices so that industrial activities are the least affected possible by expected and/or unexpected price changes in the oil market. This issue will have ramifications for the investment decisions of private firms as gasoline derived from crude oil is used as an input to the production process and natural gas can serve as a substitute for crude oil in consumption or production of other energy sources.

In this article, a nonlinear autoregressive distributed lags model has been implemented to empirically investigate the dynamic oil price pass-through. Our empirical framework helps discern the effects of strength of crude oil price effects with respect to their positive and negative changes. Using spot prices of WTI crude oil, gasoline, and Henry Hub natural gas, we find that both gasoline and natural gas prices significantly adjust to changes in the price of oil. Moreover, asymmetric price reaction is observed in the short-run for the gasoline and in the long-run for the natural gas. We interpret this as evidence that the gasoline price absorbs oil price shocks more quickly that the natural gas price does, because crude oil constitutes the main feedstock for the production of gasoline. The differences in nature between crude oil and natural gas markets (i.e., global versus regional markets) also explain this result. As natural gas prices vary more with regional factors (e.g., the demand characteristics of the market, the region's access to different supply basins, pipelines and storage facilities), the changes in oil prices owing principally to global factors (e.g., economic recession, financial crises, geopolitical tension, and wars) are likely to affect natural gas prices over the long-run.

Another important finding is that negative oil shocks have greater effects than positive oil shocks. The greater asymmetric impact of the decreases in oil prices can be attributed to downward price expectation spirals that affect gasoline and natural gas prices during downward economic conditions. This finding implies that the share of consumer and producer 
budget devoted to purchase gasoline and natural gas is greater in times of declining oil prices than in time of rising oil prices. It is worth noting however that the impact of oil price increases on gasoline prices should be more restrained because gasoline prices come under scrutiny by the public authorities on daily basis, which react to higher gasoline prices by reducing its discretionary budget. To the extent that oil prices experience substantial variations through time owing to both expected (e.g., market states and production quotas) and unexpected events (e.g., natural disasters, conflict, political tension and war), the results of this research are crucial for policymakers to draw the national energy outlook and for companies to hedge the energy risk. The growing financialization of the commodity markets under consideration, which manifests itself in increased volume of derivatives trading and activity of financial and institutional investors (e.g., commodity index funds, hedge funds and large investment banks), also strongly urge financial actors to give heed to the short- and/or long-run asymmetric price relationships. Typically, speculators may have interest to adapt their trading strategies to the complex oil-gasoline price links over the short-run as the reaction of gasoline prices to oil shocks can be negative or positive, depending on the specific factors affecting the gasoline market as well as on the government discretionary spending adjustments. The asymmetry of energy price adjustments also conveys valuable information for commodity investments because financial herding during oil price decreases and backwardation during oil price increases are likely to become stronger in financialized commodity markets. 


\section{References}

Al Gudhea, S., Kenc, T., Dibooglu, S., 2007. Do retail gasoline prices rise more readily than they fall? A threshold cointegration approach. Journal of Economics and Business 59, 560-574.

Aloui, R., Ben Aïssa, M.S, Hammoudeh, S., Nguyen, D.K., 2013. Extreme risk management in oil and natural gas markets. Working Paper, IPAG Business School.

Aloui, C., Nguyen, D.K., Njeh, H., 2012. Assessing the impacts of oil price fluctuations on stock returns in emerging markets. Economic Modelling 29, 2686-2695.

Arouri, M., Nguyen, D.K., 2010. Oil prices, stock markets and portfolio investment: evidence from sector analysis in Europe over the last decade. Energy Policy 38, 4528-4539.

Asche, F., Osmundsen, P., Sandsmark, M., 2006. The UK market for natural gas, oil and electricity: are the prices decoupled? Energy Journal 27, 27-40.

Bachmeier, L.J., Griffin, J.M., 2003. New evidence on asymmetric gasoline price responses. Review of Economics and Statistics 85, 772-776.

Bacon, R.W., 1991. Rockets and feathers: the asymmetric speed of adjustment of UK retail gasoline prices to cost changes. Energy Economics 13, 211-218.

Blair, B.F., Rezek, J.P., 2008. The effects of hurricane Katrina on price pass-through for Gulf Coast gasoline. Economics Letters 98, 229-234.

Borenstein, S., Cameron, A.C., Gilbert, R., 1997. Do gasoline prices respond asymmetrically to crude oil price changes? Quarterly Journal of Economics 112, 305-339.

Borenstein, S., Shephard, A., 2002. Sticky prices, inventories, and market power in wholesale gasoline markets. Rand Journal of Economics 33, 116-139.

Brown, S.P.A., Yucel, M.K., 2008. What drives natural gas prices? Energy Journal 29, 45-60.

Chen, L.H., Finney, M., Lai, K.S., 2005. A threshold cointegration analysis of asymmetric price transmission from crude oil to gasoline prices. Economics Letters 89, 233-239.

Ciner, C., 2001. Energy shocks and financial markets: nonlinear linkages. Studies in Nonlinear Dynamics and Economics 5, 203-212.

Cologni, A, Manera, M., 2008. Oil prices, inflation and interest rates in a structural cointegrated VAR model for the G-7 countries. Energy Economics 38, 856-888.

Engle, R.F., 1982. Autoregressive conditional heteroskedasticity with estimates of the variance of United Kingdom inflation. Econometrica 50, 987-1007.

Engle, R.F., Granger, C.W.J., 1987. Cointegration and error correction: representation, estimation and testing. Econometrica 55, 251-276.

Frey, G., Manera, M., 2007. Econometric models of asymmetric price transmission. Journal of Economic Surveys $21,349-415$.

Granger, C.W.J., 1981. Cointegrating variables and error correcting models. Working Paper, University of California, San Diego, California.

Grasso, M., Manera, M., 2007. Asymmetric error correction models for the oil-gasoline price relationship. Energy Policy 35, 156-177.

Grégoire, V., Genest, C., Gendron, M., 2008. Using copulas to model price dependence in energy markets. Energy risk, 58-64.

Hamilton, J.D., 1983. Oil and the macroeconomy since World War II. Journal of Political Economy 91, 228-248.

Hamilton, J.D., 2003. What is an oil shock? Journal of Econometrics 113, 363-398.

Hartley, P.R., Medlock III, K.B., Rosthal, J., 2008. The relationship of natural gas to oil prices. Energy Journal 29, 47-65.

Honarvar, A., 2009. Asymmetry in retail gasoline and crude oil price movements in the United States: an application of hidden cointegration technique. Energy Economics 31, 395-402. 
Hooker, M.A., 1996. What happened to the oil price-macroeconomy relationship? Journal of Monetary Economics $38,195-213$.

Johansen, S., 1988. Statistical analysis of cointegration vectors. Journal of Economic Dynamics and Control 12, 231-254.

Jones, C.M., Kaul, G., 1996. Oil and the stock markets. Journal of Finance 51, 463-491.

Kilian, L., 2008. Exogenous oil supply shocks: how big are they and how much do they matter for the U.S. economy? Review of Economics and Statistics 90, 216-240.

Lardic, S., Mignon, V., 2008. Oil prices and economic activity: an asymmetric cointegration approach. Energy Economics 30, 847-855.

Meyler, A., 2009. The pass through of oil prices into consumer liquid fuels prices in an environment of high and volatile oil prices. Energy Economics 6, 867-881.

Mork, K.A., 1989. Oil and the macroeconomy when prices go up and down: An extension of Hamilton's results. Journal of Political Economy 97, 740-744.

Sadorsky, P., 1999. Oil price shocks and stock market activity. Energy Economics 21, 449-469.

Serletis A., Ricardo, R., 2004. Testing for common features in North American energy markets. Energy Economics 26, 401-414.

Shin, Y., Yu, B., Greenwood-Nimmo, M., 2011. Modelling asymmetric cointegration and dynamic multipliers in an ARDL framework. In William C. Horrace and Robin C. Sickles (Eds.), Festschrift in Honor of Peter Schmidt. New York (NY): Springer Science \& Business Media.

Villar, J.A., Joutz, F.L., 2006. The relationship between crude oil and natural gas prices. Energy Information Administration, Washington D.C.

Zivot, E., Andrews, K., 1992. Further evidence on the great crash, the oil price shock, and the unit root hypothesis. Journal of Business and Economic Statistics 10, 251-270.

Yucel, M.K., Guo, S., 1994. Fuel taxes and cointegration of energy prices. Contemporary Economic Policy 12, 33-41. 